\title{
Sistem Pemantauan Kapasitas Sampah Berbasis loT (SiKaSiT) untuk Pencegahan Banjir di Wilayah Sungai Citarum Bojongsoang Kabupaten Bandung
}

\author{
IoT-Based Trash Capacity Monitoring System (SiKaSiT) for \\ Prevention of Floods in Citarum River Bojongsoang Bandung
}

\author{
HUSNENI MUKHTAR ${ }^{1 *}$, DOAN PERDANA ${ }^{1}$, PARMAN SUKARNO $^{2}$, ASEP MULYANA ${ }^{3}$
}

\footnotetext{
${ }^{1}$ Fakultas Teknik Elektro, Universitas Telkom, Jl Telekomunikasi 1, Bandung 40257

${ }^{2}$ Fakultas Teknik Informatika, Universitas Telkom, JI Telekomunikasi 1, Bandung 40257

${ }^{3}$ Fakultas IImu Terapan, Universitas Telkom, JI Telekomunikasi 1, Bandung 40257

Email: husnenimukhtar@telkomuniversity.ac.id
}

\begin{abstract}
The needs of flood disaster management encourage various efforts from all scientific disciplines of science, technology, and society. This article discusses the efforts to prevent flooding due to the habit of disposing of their waste into rivers through an innovative waste management system using the approach and application of Internet-based technology (IOT). Previous research has produced a prototype of the waste level monitoring system. In this research, the prototype was developed into a practical technology, called SiKaSiT (IoT Based Trash Capacity Monitoring System). This technology aims to assist janitor in monitoring, controlling and obtaining information about trash capacity and disposal time easily through an application on the smartphone in real-time and online. The system was made using a level detection sensor integrated with NodeMCU and Wi-Fi, MQTTbroker-protocol and Android-based application. Furthermore, the system was implemented in Bojongsoang adjacent to the Citarum river, where the water often overflowed due to the high rainfall and volume of trash around it. The results of system testing in the field shown good performance with value ranges of reliability is $(99,785-99,944) \%$ and availability is $(99,786$ - 99,945)\%. SiKaSiT has several advantages over other similar systems. First, there is an application on the user's smartphone to monitor the capacity of trash and notification for full-bin. Second, the ability to operate on a small-bandwidth internet network because the throughput time is only around $0.59 \mathrm{kbps}$, thereby saving internet bandwidth consumption. This system has also helped overcome the problem of community trash management in Kampung Cijagra, where $60 \%$ of them gave feedback "agree" and the rest "strongly agree".
\end{abstract}

Keywords: waste, IoT, monitoring, flooding, river

\begin{abstract}
ABSTRAK
Kebutuhan penanggulangan bencana banjir mendorong berbagai upaya dari semua disiplin ilmu baik dari bidang sains, teknologi dan sosial. Dalam artikel ini, penulis membahas upaya pencegahan banjir akibat kebiasaan membuang sampah ke sungai melalui inovasi sistem manajemen sampah menggunakan pendekatan dan penerapan teknologi berbasis Internet of Things (IoT). Pada riset sebelumnya telah dihasilkan sebuah prototype sistem monitoring level sampah. Kemudian pada riset ini prototype tersebut dikembangkan menjadi suatu teknologi tepat guna, dinamakan dengan SiKaSiT (Sistem Pemantauan Kapasitas Sampah Berbasis loT). Teknologi ini bertujuan untuk membantu petugas kebersihan dalam memantau, mengontrol dan memperoleh informasi tentang kapasitas sampah dan waktu pembuangan sampah dengan mudah melalui aplikasi di smartphone secara real time dan online. Sistem dibuat dengan menggunakan sensor deteksi ketinggian sampah yang diintegrasikan dengan NodeMCU dan Wi$\mathrm{Fi}$, protokol MQTT broker dan aplikasi berbasis android pada smartphone. Selanjutnya sistem diimplementasikan di daerah Bojongsoang yang berdekatan dengan sungai Citarum yang airnya sering meluap akibat tingginya curah hujan dan volume sampah di sekitarnya. Hasil pengujian sistem di lapangan menunjukkan kinerja yang baik dengan kisaran nilai reliability adalah $(99,785-99,944) \%$ dan availability adalah $(99,786$ - 99,945) \%. SiKaSiT memiliki beberapa kelebihan dibanding sistem serupa lainnya. Pertama, adanya aplikasi di smartphone pengguna untuk memonitor kapasitas sampah dan notifikasi saat tempat sampah penuh. Kedua, sistem mampu beroperasi pada jaringan internet bandwith kecil karena waktu throughput-nya hanya sekitar 0,59 kbps sehingga menghemat konsumsi bandwith internet. Sistem ini juga telah membantu menanggulangi permasalahan pengelolaan sampah masyarakat Kampung Cijagra, dimana 60\% masyarakat memberi feedback "setuju" dan sisanya "sangat setuju".
\end{abstract}

Kata kunci: Sampah, loT, Monitoring, Banjir, Sungai 


\section{PENDAHULUAN}

\subsection{Latar Belakang}

Bencana banjir ditinjau dari aspek ekologis merupakan peristiwa fisik yang terjadi di lingkungan hidup manusia. Banjir dan manusia saling berkaitan erat, dimana banjir akan mempengaruhi kehidupan manusia itu sendiri sedangkan manusia memilki andil dalam terjadinya banjir ${ }^{(1)}$. Kerusakan dalam ekosistem manusia akibat perbuatan dirinya sendiri disebut pencemaran lingkungan hidup. Banjir, salah satunya, adalah kerusakan ekosistem manusia yang disebabkan oleh aktivitas manusia secara langsung dan tidak langsung, seperti penebangan hutan, alih fungsi lahan reservoir air serta membuang sampah ke sembarang tempat atau ke sungai.

Slogan "Buanglah sampah pada tempatnya" nampaknya tidak lagi efektif dalam memberikan hasil positif dalam hal penanggulangan sampah. Berdasarkan analisis distribusi frekuensi yang mempengaruhi tingkat partisipasi masyarakat dalam mengelola sampah rumah tangga atau tempatnya bermukim diantaranya dipengaruhi oleh tingkat pendidikan, pendapatan, keadaan lingkungan dan sikap terhadap lingkungan ${ }^{(2)}$. Selain itu, pengetahuan tentang perda sampah dan kesediaan membayar retribusi sampah berkorelasi positif terhadap cara pengelolaan sampah $^{(3)}$.

Di lain pihak, produksi sampah tidak sebanding dengan sistem pengangkutan dan pengelolaan sampah, sehingga sampah kian menumpuk dari hari ke hari. Penumpukan sampah ini dikhawatirkan menjadi sumber penyakit jika dibiarkan terlalu lama di dekat pemukiman, sehingga menumpuk sampah tersebut di pinggir sungai ataupun membuangnya ke sungai menjadi salah satu cara alternatif yang dilakukan oleh masyarakat yang tinggal di sekitar sungai. Proses pembuangan sampah seperti inilah yang akan menyebabkan pendangkalan sungai dan akhirnya air akan meluap ke permukaan. Hal ini menjadi cikal bakal terjadinya banjir di setiap $\operatorname{musim}^{(1,3)}$.

Oleh karenanya, diperlukan upaya pencegahan dan penanggulangan banjir agar dampaknya tidak semakin meluas dan menimbulkan kerugian materi dan korban jiwa. Upaya yang dapat dilakukan terdiri dari pendekatan struktural dan non struktural. Normalisasi sungai, pembangunan waduk, pengurangan debit puncak banjir, pembuatan sumur resapan, Early Warning System (EWS) untuk banjir adalah beberapa cara upaya struktural. Sedangkan upaya non-struktural dilakukan melalui kegiatan manusia yang diatur dan disesuaikan dengan lingkungan agar secara harmonis dan serasi, seperti pengaturan pengendalian penggunaan lahan, penegakan aturan lingkungan, pengawasan dan penyuluhan, dan lain sebagainya ${ }^{(3,4)}$.

Penelusuran metode riset pengelolaan atau penanganan sampah lebih dominan dilakukan dengan cara waste management atau daur ulang bernilai ekonomi ${ }^{(5,6)}$, konsep Zero Waste yang menawarkan pengelolaan sampah dimulai dari peniadaan sampah, daur ulang, reduksi dan pemulihan barang bekas ${ }^{(7)}$, sistem pemilahan sampah logam dan non-logam ${ }^{(8)}$, dikomposkan dan sebagainya.

Sementara itu, pengelolaan sampah yang hanya mengandalkan petugas kebersihan dalam mengosongkan tempat sampah di lingkungan pemukiman penduduk dan mengangkutnya ke Tempat Penampungan Sementara (TPS) tidak sedikit menimbulkan permasalahan baru. Sering kali tempat sampah penuh lebih dahulu sebelum jadwal pengambilan sampah tiba. Hal ini tentunya menciptakan keadaan yang tidak nyaman di sekitar rumah akibat bau tidak sedap yang ditimbulkan sampah, merusak kerapian lingkungan perumahan dan tidak menutup kemungkinan akan menjadi sumber penyakit. Tidak rutinnya jadwal petugas kebersihan mendatangi pemukiman penduduk sehingga tempat sampah yang terdapat di lingkungan pemukiman terpaksa dibiarkan dalam kondisi penuh sering mengakibatkan munculnya kebiasaan buruk pada sebagian masyarakat yaitu membuang dan menumpuk sampah di pinggir sungai. Kebiasaan ini sering dijumpai pada masyarakat yang tinggal di dekat atau sepanjang aliran sungai. Atau sebaliknya, tempat sampah sering kosong karena penghuni rumah jarang berada di rumah atau rumah kosong sehingga kinerja petugas kebersihan menjadi kurang efektif karena harus memeriksa setiap tempat sampah untuk dikosongkan. Salah satu solusi untuk mengatasi permasalahan tersebut adalah dengan cara memantau kapasitas sampah dalam bin agar petugas kebersihan dapat memonitor kondisi kapasitas sampah dalam bin dan mengosongkan tempat sampah yang sudah penuh dengan segera. Dengan demikian cara ini dapat menjadi suatu solusi alternatif yang cukup strategis untuk mencegah pembuangan sampah sembarangan ataupun ke sungai serta menciptakan lingkungan pemukiman penduduk yang lebih bersih dan sehat.

Riset pemantauan volume sampah pada tempat sampah telah dilakukan dengan beberapa metode seperti penggunaan sensor ultrasonik berbasis mikrokontroler dengan output buzzer dan LED pada tempat sampahnya ${ }^{(9)}$, penggunaan sensor infra-red ${ }^{(10,11,12)}$ dan pembacaannya dikirimkan ke serverl PC 
menggunakan real time operating system pada mikrokontroler ${ }^{(13)}$.

Teknologi pengiriman dan monitoring yang lebih maju lagi adalah penggunaan jaringan internet dengan menggunakan protokol MQTT. Message Queue Telemetry Transport (MQTT), protokol yang bekerja pada protokol TCP/IP, dikenal sebagai protokol yang memiliki ukuran paket kecil dan membutuhkan catu daya rendah ${ }^{(14)}$. Protokol ini cocok digunakan sebagai dukungan Internet of Things (IOT) karena dapat menghubungkan M2M (machine-to-machine)(15).

Pemanfaatan protokol MQTT telah dilaporkan dalam beberapa riset seperti sistem kontrol beberapa sensor menggunakan jaringan lokal namun pemakaian jaringan publik hanya diuji untuk kontrol satu sensor saja ${ }^{(13)}$ dan sistem pemantauan tempat sampah dengan pemberitahuan tingkat kenaikan sampah namun melalui media sosial menggunakan aplikasi

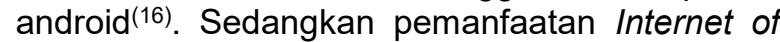
Things menjadi pilihan dari kedua penelitian tersebut. Hal ini sangatlah wajar karena di tahun mendatang diprediksikan bahwa hampir semua perangkat akan terkoneksi ke internet, tidak hanya komputer smartphone, tapi juga instrumen-instrumen yang digunakan dalam kehidupan sehari-hari (17).

Dari riset penulis sebelumnya, pemanfaatan teknologi Internet of Things (IoT) telah digunakan untuk membuat sebuah prototype sistem pemantauan sampah dengan memanfaatkan sensor jarak, mikrokontroller berupa NodeMCU dan koneksi internet. Hasil pengujian ketersediaan dan keandalan prototype ini adalah di rentang 99,833\% dan 99,905\% untuk pengiriman paket $100 \mathrm{~ms}$ dan $1000 \mathrm{~ms}^{(18)}$. Selanjutnya prototype tersebut dikembangkan lebih jauh lagi dan diimplementasikan pada kondisi real di lapangan, yang dilaporkan pada artikel ini.

\subsection{Tujuan Penelitian}

Pengembangan dan pemanfaatan IoT pada sistem monitoring kapasitas tempat sampah terus dilakukan, yaitu dengan menambah fitur kemudahan bagi petugas kebersihan. Oleh karenanya, tujuan utama riset ini adalah untuk membantu kinerja petugas kebersihan agar lebih efektif dan efisien dari segi tenaga dan waktu karena aplikasi sistem monitoring hanya akan memberikan notifikasi tempat sampah yang sudah penuh saja.

Petugas kebersihan yang bertugas akan mendapatkan pemberitahuan kapasitas sampah dari beberapa tempat sampah secara online dan real time melalui aplikasi android pada smartphone. Selain itu, dengan adanya riset ini diharapkan dapat menumbuhkan kesadaran masyarakat dalam membuang sampah pada tempat yang telah disediakan dan bukan lagi dibiarkan berserakan tumpah ke jalan atau dibuang ke sungai.

\section{BAHAN DAN METODE}

\subsection{Desain SiKaSiT}

Pengembangan sistem monitoring kapasitas tempat sampah, atau disingkat dengan SiKaSiT, dilakukan dengan beberapa tahapan. Pertama, sensor ultrasonik HC-SR04 digunakan untuk mendeteksi level atau ketinggian sampah di dalam tempat sampah. Kedua, proses akuisisi data sensor dimulai dari NodeMCU sebagai mikrokontroller dan pengiriman data menggunakan modem Wi-fi. Modul ini dilengkapi dengan catu daya berupa powerbank yang diperoleh dari sistem photovoltaic atau selfcharged ke sumber listrik jika sumber cahaya matahari tidak mendukung. Ketiga, proses pengumpulan data sensor secara online dan real-time dilakukan dengan menggunakan MQTT broker sebagai protokol loT. Keempat, membuat dan memasang sebuah aplikasi berbasis android pada smartphone untuk menampilkan data level sampah dan notifikasi tempat sampah yang sudah penuh.

Alasan penggunaan IoT pada SiKaSiT adalah karena loT merupakan sebuah penemuan yang mampu menjembatani dan menyelesaikan permasalahan sosial masyarakat melalui teknologi dengan konektivitas internet. Deskripsi teknis aplikasi loT, seperti yang ditampilkan pada Gambar 1, lebih tepatnya diformulasikan untuk komunikasi Machine to Machine (M2M) dan komunikasi Device to Device (D2D)(19), sehingga aplikasi loT dapat diinterpretasikan salah satunya sebagai komunikasi M2M.

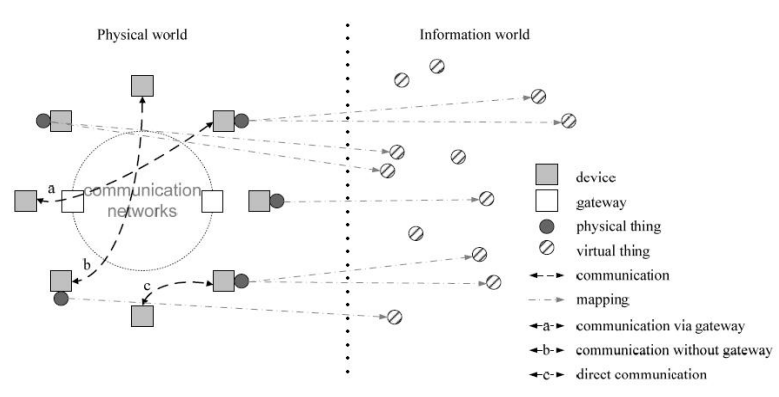

Gambar 1. Deskripsi teknis sistem loT (19)

Teknis sistem loT yang digunakan pada SiKaSiT adalah teknis sistem a (Gambar 1), yaitu menggunakan internet sebagai jaringan telekomunikasi dan free Wi-Fi sebagai gateway (Gambar 2). Sedangkan MQTT broker jenis mosquito yang ditanam di sebuah virtual private server (VPS) dengan sistem operasi Linux Ubuntu 16.04.4 digunakan sebagai pengganti 
server. Selanjutnya data pada server akan ditampilkan pada smartphone melalui aplikasi buatan berbasis android menggunakan software Android studio untuk tujuan monitoring keadaan kapasitas sampah di setiap tempat sampah.

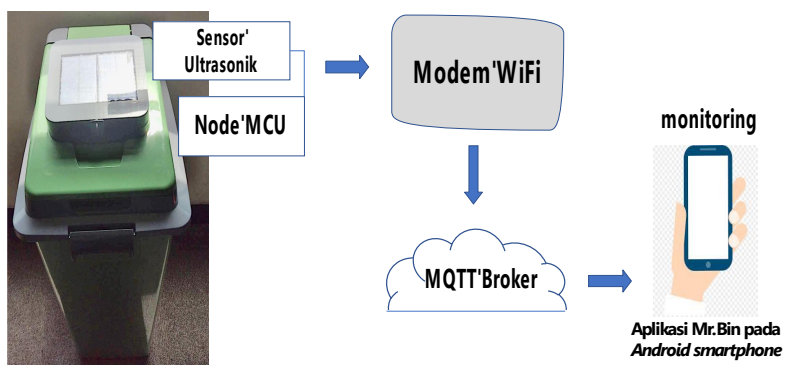

Gambar 2. Skema sistem monitoring kapasitas tempat sampah (SiKaSiT)

\subsection{Metode}

Implementasi SiKaSiT diujicobakan di suatu daerah yang dilewati sungai yaitu Kampung Cijagra yang terletak di Jl. Cijagra Bojongsoang Kabupaten Bandung. Daerah ini sering dilanda banjir karena dilewati oleh sungai Citarum dan titik pertemuan dari sungai Cikapundung dan sungai Ciatela. Kondisi lingkungan masyarakat yang minim tempat pembuangan sampah serta masih banyak praktik pembuangan sampah di sungai yang ditemui di lapangan (Gambar 3). Pengujian sistem dilakukan pada bulan Januari April 2019.

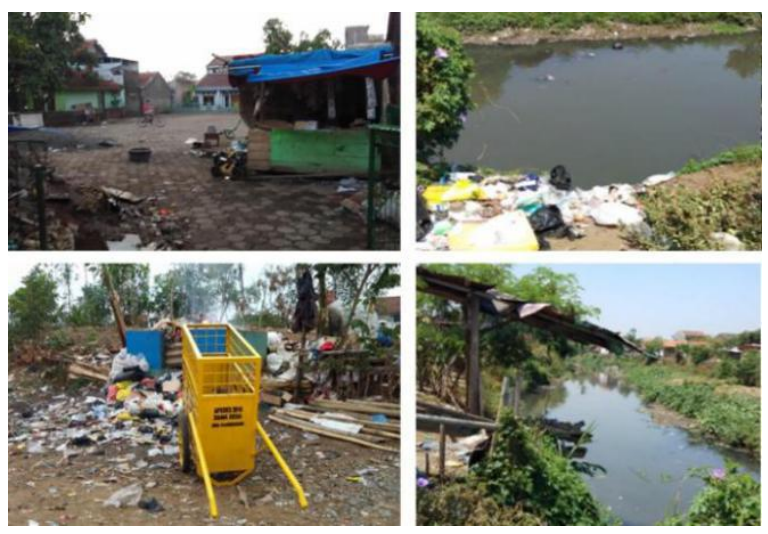

Gambar 3. Kondisi lingkungan dan sungai di Kampung Cijagra Bojongsoang Kab. Bandung

Cara kerja SiKaSiT dalam memonitor ketinggian sampah di setiap bin dan menampilkan notifikasinya di smartphone pengguna dapat dilihat pada Gambar 4a. Proses akuisisi data ketinggian sampah, yang diperoleh dari tiga tempat sampah (bin) yang disebar di tiga titik/ tempat di Kampung Cijagra, dideteksi secara berkala oleh sensor HC-SR04 dan diolah oleh mikrokontroler jenis nodeMCU v3. Setelah nodeMCU terhubung dengan modem Wi-Fi, data ketinggian sampah dari ketiga bin dikirim oleh modem Wi-Fi ke server. Server yang digunakan adalah MQTT broker mosquito yang ditanamkan dalam virtual private server (VPS) melalui jaringan internet. Setelah data diproses oleh server, selanjutnya petugas kebersihan dapat mengakses data tersebut pada smartphone melalui aplikasi buatan berbasis android. Jika data sensor sudah melewati nilai batas ketinggian yang ditentukan, maka selain tampilan status keadaan kapasitas bin, sistem juga memberikan notifikasi langsung ke aplikasi yang digunakan oleh user di smartphone-nya. Status atau keadaan ketiga bin tersebut dapat dipantau kapan saja oleh petugas kebersihan seperti yang diilustrasikan pada Gambar 4b. Atau petugas tidak perlu memantau sama sekali kondisi tempat sampah karena sistem akan memberikan notifikasi di smartphone ketika ada satu atau beberapa tempat sampah yang sudah penuh dan harus diambil dan dibuang isinya.

Pengujian dan pengambilan data pada riset ini terbagi ke dalam tiga tahap berikut,

a) Uji performansi hardware dan software pada sistem

b) Uji performansi SiKaSiT, meliputi

- Pengamatan waktu delay pengiriman data dari saat setelah sensor mendeteksi keadaan level sampah sampai data dikirimkan pada aplikasi android dan diterima oleh pengguna (end to end delay) terhadap variasi waktu jeda.

- Pengujian throughput setiap jalur pengiriman.

- Pengujian performansi realibility dan availability sistem.

- Pengambilan data performansi penggunaan aplikasi android di smartphone pada user (pengguna).

c) Uji kualitatif implementasi SiKaSiT, baik bagi petugas kebersihan maupun masyarakat setempat, melalui penilaian bobot skala atau feedback pada kuesioner.

Sedangkan implementasi SiKaSiT di lapangan dimulai dari tahap uji coba, penyuluhan dan pelatihan penggunaan sistem kepada masyarakat sampai dengan penggunaan sistem oleh penggunanya meliputi petugas kebersihan dan masyarakat setempat.

\section{HASIL DAN PEMBAHASAN}

\subsection{Pemasangan Sistem pada Tempat Sampah}

Tempat sampah ditempatkan di lokasi yang banyak terkena sinar matahari karena sistem ini memiliki catu daya dari powerbank yang diisi melalui panel surya 2WP yang ditempatkan di atas tutup bin (Gambar 5a). Di bawah panel surya terdapat sistem integrasi dari akuisisi dan 
pengiriman data ketinggian sampah yang dihubungkan ke catu daya, mikrokontroler NodeMCU v3 dan modem Wi-Fi (Gambar 5b). Kebutuhan daya setiap sistem tempat sampah disuplai dari solar panelnya masing-masing. Indikator LED yang berwarna merah akan menyala jika daya sedang diisi ke dalam powerbank (Gambar 5c), dengan kata lain panel surya telah menangkap dan memproses energi dari cahaya matahari. Jika cuaca tidak mendukung untuk memperoleh cahaya matahari, maka pengguna dapat langsung mengisi powerbank dengan menghubungkannya ke sumber listrik PLN. Selanjutnya tempat sampah dapat digunakan setelah memastikan semua kabel terhubung dan sistem telah ditutup dan dikunci dengan baik (Gambar $5 \mathrm{~d}$ )

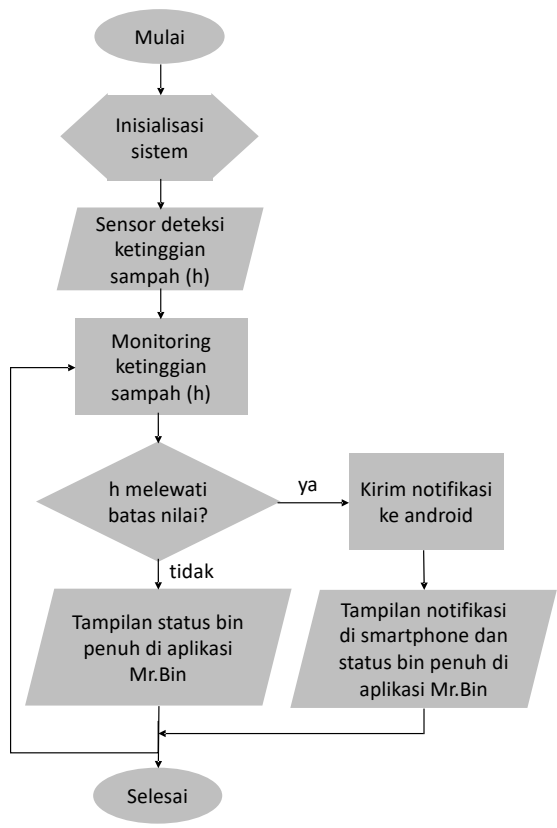

(a)

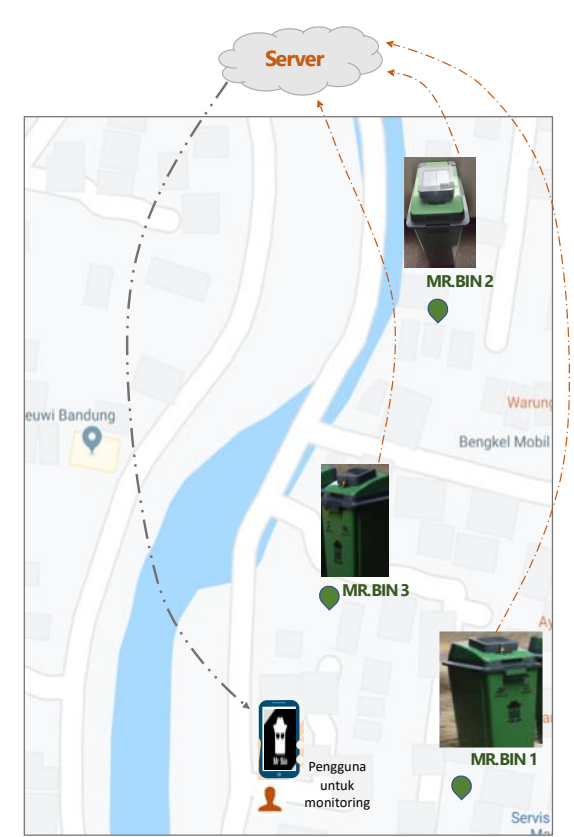

(b)

Gambar 4. (a) Diagram alir kinerja SiKaSiT dan (b) Ilustrasi akuisisi dan monitoring data kondisi kapasitas sampah dalam bin untuk diteruskan ke smartphone pengguna melalui server
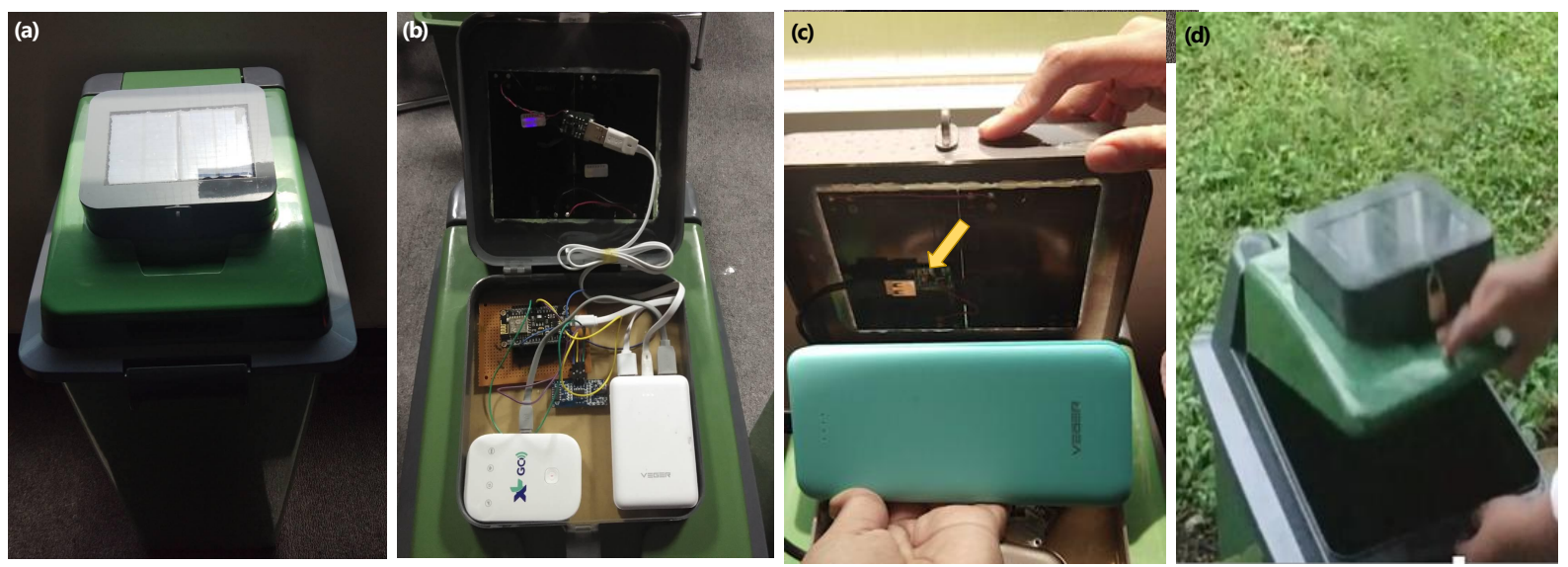

Gambar 5. Tempat sampah/ bin pada SiKaSiT. (a) Penempatan panel surya dan (b) kotak yang berisi sistem integrasi akuisisi dan pengiriman data dari modem Wi-Fi di atas tutup bin, (c) Indikator LED berwarna merah jika daya sedang diisi ke dalam powerbank, (d) Kotak ditutup dan dikunci dengan baik sebelum digunakan

\subsection{Uji performansi Hardware dan Software pada Sistem}

Pengujian performansi hardware meliputi uji fungsionalitas sensor ultrasonik HC-SR04 dan mikrokontroler NodeMCU dan pengujian software meliputi uji fungsionalitas MQTT broker dan aplikasi Mr. Bin pada android smartphone disajikan pada Tabel 1 dan Tabel 2 secara 
berturut-turut. Hasil pengujian setiap bagian hardware dan software adalah sangat baik, yaitu sesuai dengan fungsinya masing-masing.

\subsection{Uji Performansi SiKaSiT}

\subsubsection{Pengujian waktu end to end delay pengiriman data}

Pengujian performansi SiKaSiT dimulai dengan pengujian waktu end to end delay total pengiriman data dari node-MCU hingga dikirimkan ke aplikasi android di smartphone pengguna dengan tiga variasi waktu jeda dan variasi jumlah bin yang aktif (ON) seperti yang disajikan pada Tabel 3. Pengujian ini dilakukan dengan menghitung total waktu rerata dari node-MCU ke MQTT broker dan dari MQTT broker ke aplikasi android di smartphone. Selanjutnya, dilakukan perhitungan rerata waktu end to end delay pengiriman data yang dibutuhkan untuk setiap bin.

Pengujian waktu end to end delay pengiriman data ini dihasilkan dalam rentang skala millidetik atau milisecond (ms), dimana nilai ini bisa dikatakan sebagai waktu total pengiriman yang terbilang sangat cepat. Hasil waktu berdasarkan variasi jumlah bin pun tidak berbeda secara signifikan, yaitu masih dalam rentang yang hampir sama. Bila dibandingkan dengan hasil penelitian yang dilakukan oleh Mohammad F.R. dkk ${ }^{(19)}$, hasil end to end delay pengiriman MQTT yang mereka peroleh adalah di rentang 5.05 6.28 detik. Hasil ini jauh lebih lambat dari perolehan waktu di riset ini. Signifikannya perbedaaan waktu end to end delay pengiriman data ini kemungkinan disebabkan oleh kecilnya memori yang digunakan dan keadaan reconnection yang lebih sering dilakukan.

Tabel 1. Pengujian fungsionalitas hardware

\begin{tabular}{clc}
\hline No & \multicolumn{1}{c}{ Fungsi Hardware } & Keterangan \\
\hline 1 & Integrasi NodeMCU dengan Sensor HC-SR04 & Berhasil \\
2 & NodeMCU dapat terkoneksi dengan jaringan internet & Berhasil \\
3 & Sensor dapat mendeteksi ketinggian sampah & Berhasil \\
4 & NodeMCU dapat mengirimkan data dari sensor ke MQTT broker & Berhasil \\
\hline
\end{tabular}

Tabel 2. Pengujian fungsionalitas software

\begin{tabular}{clc}
\hline No & \multicolumn{1}{c}{ Fungsi Hardware } & Keterangan \\
\hline 1 & MQTT broker dapat menerima data yang dipublish oleh NodeMCU & Berhasil \\
2 & MQTT broker dapat meneruskan data yang didapat sampai aplikasi & Berhasil \\
3 & Aplikasi dapat menerima data yang diteruskan oleh MQTT broker & Berhasil \\
4 & Aplikasi dapat memberi notifikasi saat batas ketinggian sudah mencapai batas & Berhasil \\
\hline
\end{tabular}

Tabel 3. Pengujian waktu delay total pengiriman data ke setiap bin berdasarkan variasi waktu jeda pengiriman data $100 \mathrm{~ms}, 500 \mathrm{~ms}$ dan $1000 \mathrm{~ms}$

\begin{tabular}{|c|c|c|c|c|c|c|c|c|c|}
\hline \multirow{3}{*}{$\begin{array}{c}\text { Waktu jeda } \\
\text { pengiriman } \\
\text { data }(\mathrm{ms})\end{array}$} & \multicolumn{6}{|c|}{ Rerata end to end delay (ms) } & \multicolumn{3}{|c|}{$\begin{array}{l}\text { Rerata end to end delay per } \\
\text { bin (ms) }\end{array}$} \\
\hline & \multirow{2}{*}{$\begin{array}{l}\begin{array}{l}1 \text { bin } \\
\text { ON }\end{array} \\
\qquad \text { bin-1 }\end{array}$} & \multicolumn{2}{|c|}{2 bins ON } & \multicolumn{3}{|c|}{3 bins ON } & \multirow{2}{*}{$\begin{array}{l}1 \text { bin } \\
\text { ON }\end{array}$} & \multirow{2}{*}{$\begin{array}{l}2 \text { bins } \\
\text { ON }\end{array}$} & \multirow{2}{*}{$\begin{array}{l}3 \text { bins } \\
\text { ON }\end{array}$} \\
\hline & & bin-1 & bin-2 & bin-1 & bin-2 & bin-3 & & & \\
\hline 100 & 0.26055 & 0.27324 & 0.27580 & 0.27426 & 0.27539 & 0.27858 & 0.26055 & 0.27452 & 0.27608 \\
\hline 500 & 1.04634 & 1.05240 & 1.05818 & 1.08650 & 1.05141 & 1.04341 & 1.04634 & 1.05529 & 1.06044 \\
\hline 1000 & 2.02312 & 2.07898 & 2.04631 & 2.07020 & 2.03175 & 2.10432 & 2.02312 & 2.06264 & 2.06875 \\
\hline
\end{tabular}

\subsubsection{Pengujian throughput}

Perhitungan throughput atau kecepatan (rate) transfer data efektif yang diukur dalam bps (bit per second) disajikan dalam Tabel 4. Throughput adalah jumlah total kedatangan paket yang sukses, diamati pada tujuan pengiriman selama interval waktu tertentu menggunakan persamaan 1.

Throughput $=\frac{\text { jumlah data yang dikirim (bit atau byte) }}{\text { Total waktu pengiriman data }(s)}$..
Pengaruh perubahan jumlah bin terhadap nilai throughput pada Tabel 4 adalah bernilai positif, dimana perubahan kedua kondisi ini akan saling mempengaruhi. Semakin banyak jumlah bin, maka jumlah paket data yang dikirim akan mengalami penurunan baik saat menggunakan jeda pengiriman $1000 \mathrm{~ms}, 500 \mathrm{~ms}$ maupun 100 ms. Tentu saja hal ini akan berpengaruh terhadap turunnya nilai throughput.

Nilai rerata throughput tertinggi dan terendah dihasilkan oleh kondisi 2 bins yang menyala yaitu 
berturut-turut bernilai 597,17 bps (delay $100 \mathrm{~ms}$, MQTT broker-aplikasi) dan 64.03 bps (delay 1000 ms, NodeMCU-MQTT broker). Nilai throughput ini termasuk nilai yang cukup kecil, dengan kata lain protocol MQTT yang digunakan untuk sistem monitoring berbasis loT ini hanya membutuhkan koneksi internet dengan bandwith yang kecil juga, yaitu minimal senilai throughput terbesarnya 597,17 bps atau 0,59 kbps. Kebutuhan atau konsumsi bandwith internet yang dihasilkan riset SiKaSiT ini jauh lebih kecil jika dibandingkan dengan penelitian lainnya yang melaporkan hasil nilai throughput adalah sebesar 9,2 Mbps atau 9200 kbps ${ }^{(20)}$. Oleh karena itu, SiKaSiT ini mampu berjalan dalam kondisi bandwith internet yang kecil atau rendah sehingga lebih menguntungkan bagi penggunanya, yaitu biaya penggunaan internet lebih murah dan tidak perlu koneksi internet dengan bandwith besar seperti 3G dan 4G.

\subsubsection{Pengujian realibility dan availability}

Tujuan pengujian realibility dan availability pada keseluruhan sistem adalah untuk meninjau tingkat keberhasilan dan fungsi sistem dalam mengirimkan data. Realibility, atau kemampuan sistem dalam mengirimkan data agar diterima oleh pengguna dalam jangka waktu tertentu, dihitung dengan persamaan 2. Sedangkan availability, atau keadaan sistem dapat menjalankan fungsinya dalam suatu jangka waktu, ditentukan dengan persamaan 3 . Realibility dan availability dihitung secara keseluruhan sistem yaitu dari sensor ke aplikasi Mr. Bin. Keadaan sent artinya keadaan paket data yang berhasil diterima server MQTT broker dan dikirim ke aplikasi Mr. Bin, sedangkan keadaan failed adalah untuk kondisi sebaliknya.

$$
\begin{aligned}
& \text { Realibility }=\frac{\left(n_{\text {data_sent }}-n_{\text {data_failed }}\right)}{n_{\text {data_sent }}} \times 100 \% \\
& \text { Availability }=\frac{n_{\text {data_sent }}}{\left(n_{\text {data_sent }}+n_{\text {data_failed }}\right)} \times 100 \%
\end{aligned}
$$

Nilai-nilai tersebut selengkapnya disajikan pada Tabel 5 untuk variasi jeda waktu pengiriman dan jumlah bin yang aktif. Nilai realibility dan availability sangat dipengaruhi oleh jumlah paket yang gagal ketika dikirim ke aplikasi. Untuk jumlah paket yang gagal dapat diketahui dari jumlah paket yang diterima oleh broker dikurangi dengan jumlah paket yang dikirim ke aplikasi.

Tabel 4. Hasil throughput untuk setiap jarak dan variasi jeda pengiriman

\begin{tabular}{ccccccc}
\hline \multirow{2}{*}{$\begin{array}{c}\text { Waktu jeda } \\
\text { pengiriman } \\
\text { data (ms) }\end{array}$} & \multicolumn{2}{c}{1 bin ON } & \multicolumn{2}{c}{ Rerata throughput (bps) } \\
\cline { 2 - 7 } & $\begin{array}{c}\text { NodeMCU- } \\
\text { MQTT broker }\end{array}$ & $\begin{array}{c}\text { MQTT broker } \\
\text { aplikasi }\end{array}$ & $\begin{array}{c}\text { NodeMCU- } \\
\text { MQTT broker }\end{array}$ & $\begin{array}{c}\text { MQTT broker - } \\
\text { aplikasi }\end{array}$ & $\begin{array}{c}\text { NodeMCU- } \\
\text { MQTT broker }\end{array}$ & $\begin{array}{c}\text { MQTT broker - } \\
\text { aplikasi }\end{array}$ \\
\hline 100 & 506,10 & 481,20 & 478,16 & 597,17 & 567,82 & 564,52 \\
500 & 125,97 & 123,75 & 123,27 & 148,80 & 146,28 & 145,58 \\
1000 & 65,27 & 64,18 & 64,03 & 77,20 & 75,97 & 75,86 \\
\hline
\end{tabular}

Tabel 5. Realibility dan availability sistem monitoring kapasitas sampah dalam bin untuk setiap jumlah bin yang aktif dan variasi waktu jeda pengiriman

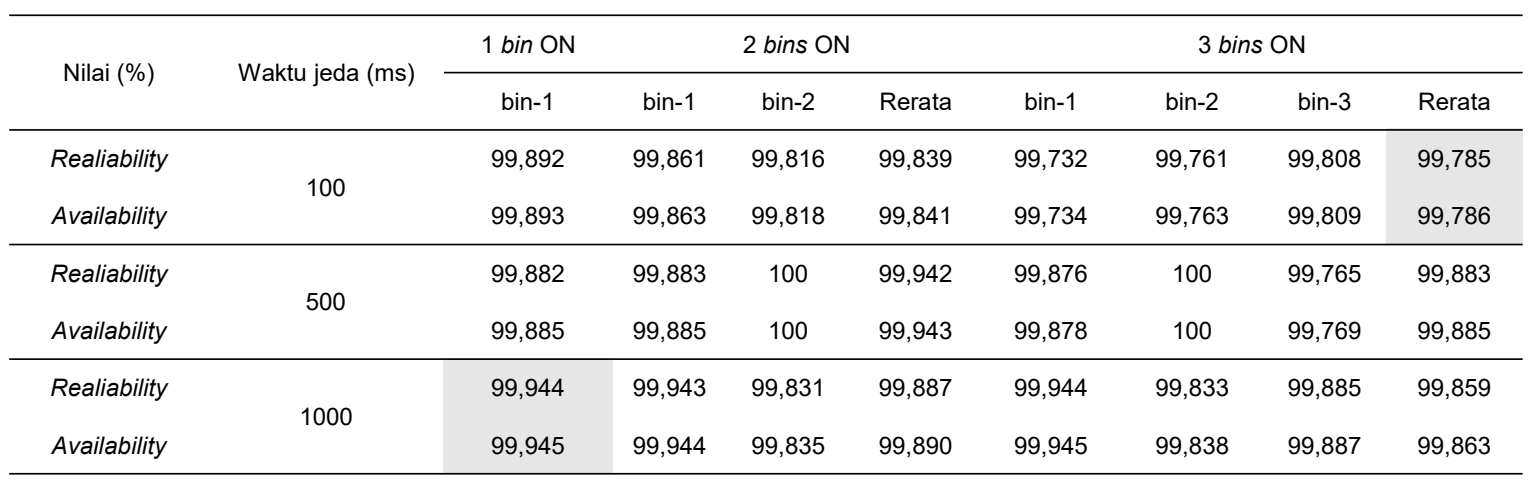


Tabel 6. Nilai realibility dan availability sistem dan rekap data pemantauan kapasitas sampah dalam bin melalui aplikasi Mr. Bin untuk waktu pemantauan secara acak selama 3 bulan

\begin{tabular}{|c|c|c|c|c|c|c|c|c|c|c|c|}
\hline \multirow[b]{2}{*}{ Tanggal } & \multirow{2}{*}{$\begin{array}{c}\text { Waktu } \\
\text { pemantauan }\end{array}$} & \multicolumn{3}{|c|}{ Bin 1} & \multicolumn{3}{|c|}{$\operatorname{Bin} 2$} & \multicolumn{3}{|c|}{ Bin 3} & \multirow{2}{*}{$\begin{array}{l}\text { Notifikasi } \\
\text { penuh } \\
\text { bin ke- }\end{array}$} \\
\hline & & Reability & Availability & $\begin{array}{c}\text { Status } \\
\left.b i n^{*}\right)\end{array}$ & Reability & Availability & $\begin{array}{c}\text { Status } \\
\left.b i n^{*}\right)\end{array}$ & Reability & Availability & $\begin{array}{c}\text { Status } \\
\left.b i n^{*}\right)\end{array}$ & \\
\hline $16 / 01 / 2019$ & 10:09:10 & $99.944 \%$ & $99.945 \%$ & 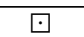 & $99.833 \%$ & $99.838 \%$ & 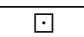 & $99.886 \%$ & $99.888 \%$ & 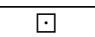 & - \\
\hline $16 / 01 / 2019$ & $17: 00: 50$ & $99.943 \%$ & $99.947 \%$ & $\square$ & $100 \%$ & $100 \%$ & $\mathrm{Q}$ & $99.888 \%$ & $99.900 \%$ & 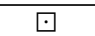 & - \\
\hline $17 / 01 / 2019$ & 08:11:55 & $99.940 \%$ & $99.944 \%$ & $\square$ & $100 \%$ & $100 \%$ & $\mathrm{P}$ & $100 \%$ & $100 \%$ & - & 3 \\
\hline $18 / 01 / 2019$ & 09:34:12 & $99.943 \%$ & $99.947 \%$ & . & $99.830 \%$ & $99.835 \%$ & $\mathrm{Q}$ & $99.885 \%$ & $99.887 \%$ & $\mathrm{Q}$ & 1 \\
\hline $19 / 01 / 2019$ & 10:00:45 & $99.940 \%$ & $99.944 \%$ & 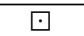 & $99.829 \%$ & $99.834 \%$ & - & $99.883 \%$ & $99.985 \%$ & - & 2,3 \\
\hline $21 / 01 / 2019$ & 07:29:57 & $99.944 \%$ & $99.945 \%$ & - & $99.833 \%$ & $99.838 \%$ & - & $99.886 \%$ & $99.888 \%$ & $\square$ & 1,2 \\
\hline $23 / 01 / 2019$ & 12:19:00 & $99.940 \%$ & $99.944 \%$ & 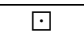 & $99.835 \%$ & $99.840 \%$ & $\odot$ & $99.883 \%$ & $99.985 \%$ & - & 3 \\
\hline $24 / 01 / 2019$ & 08:09:16 & $99.944 \%$ & $99.945 \%$ & - & $100 \%$ & $100 \%$ & 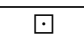 & $100 \%$ & $100 \%$ & $\square$ & 1 \\
\hline $25 / 01 / 2019$ & $07: 05: 25$ & $100 \%$ & $100 \%$ & $\mathrm{P}$ & $99.833 \%$ & $99.838 \%$ & I & $99.883 \%$ & $99.985 \%$ & - & 2,3 \\
\hline $27 / 01 / 2019$ & 07:07:36 & $99.943 \%$ & $99.947 \%$ & 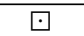 & $99.829 \%$ & $99.834 \%$ & $\mathrm{P}$ & $100 \%$ & $100 \%$ & I & 3 \\
\hline $28 / 01 / 2019$ & 07:09:19 & $100 \%$ & $100 \%$ & - & $99.829 \%$ & $99.834 \%$ & I & $99.888 \%$ & $99.900 \%$ & 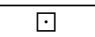 & 1,2 \\
\hline $01 / 02 / 2019$ & $09: 11: 27$ & $99.944 \%$ & $99.945 \%$ & $\square$ & $99.833 \%$ & $99.838 \%$ & $\square$ & $99.887 \%$ & $99.889 \%$ & - & 3 \\
\hline $03 / 02 / 2019$ & 09:45:48 & $100 \%$ & $100 \%$ & 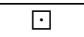 & $99.833 \%$ & $99.838 \%$ & $\odot$ & $99.886 \%$ & $99.888 \%$ & $\square$ & - \\
\hline $05 / 02 / 2019$ & 11:03:39 & $99.940 \%$ & $99.944 \%$ & - & $99.835 \%$ & $99.840 \%$ & I & $99.887 \%$ & $99.889 \%$ & - & $1,2,3$ \\
\hline $06 / 02 / 2019$ & $15: 00: 19$ & $99.940 \%$ & $99.944 \%$ & $\mathrm{P}$ & $100 \%$ & $100 \%$ & 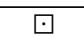 & $99.888 \%$ & $99.900 \%$ & $\square$ & - \\
\hline $08 / 02 / 2019$ & 15:00:48 & $100 \%$ & $100 \%$ & $\nabla$ & $99.835 \%$ & $99.840 \%$ & - & $100 \%$ & $100 \%$ & I & 2,3 \\
\hline $10 / 02 / 2019$ & 13:01:28 & $99.944 \%$ & $99.945 \%$ & 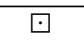 & $99.830 \%$ & $99.835 \%$ & $\nabla$ & $99.887 \%$ & $99.889 \%$ & - & 3 \\
\hline $12 / 02 / 2019$ & 18:01:04 & $99.943 \%$ & $99.947 \%$ & - & $99.833 \%$ & $99.838 \%$ & - & $99.885 \%$ & $99.887 \%$ & 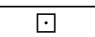 & 1,2 \\
\hline $13 / 02 / 2019$ & 11:02:08 & $99.943 \%$ & $99.947 \%$ & 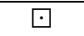 & $99.830 \%$ & $99.835 \%$ & $\odot$ & $99.883 \%$ & $99.985 \%$ & - & 3 \\
\hline $16 / 02 / 2019$ & 14:27:11 & $99.940 \%$ & $99.944 \%$ & - & $99.833 \%$ & $99.838 \%$ & - & $99.886 \%$ & $99.888 \%$ & - & $1,2,3$ \\
\hline $18 / 02 / 2019$ & 08:39:03 & $99.940 \%$ & $99.944 \%$ & 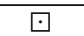 & $99.833 \%$ & $99.838 \%$ & - & $99.883 \%$ & $99.985 \%$ & $\square$ & 2 \\
\hline $19 / 02 / 2019$ & $11: 40: 50$ & $99.943 \%$ & $99.947 \%$ & $\square$ & $99.833 \%$ & $99.838 \%$ & $\odot$ & $99.887 \%$ & $99.889 \%$ & . & 3 \\
\hline $20 / 02 / 2019$ & 11:42:49 & $99.944 \%$ & $99.945 \%$ & - & $99.835 \%$ & $99.840 \%$ & I & $99.885 \%$ & $99.887 \%$ & ए & 1,2 \\
\hline $21 / 02 / 2019$ & 10:45:39 & $99.944 \%$ & $99.945 \%$ & 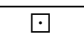 & $99.833 \%$ & $99.838 \%$ & $\square$ & $99.883 \%$ & $99.985 \%$ & $\square$ & - \\
\hline $23 / 02 / 2019$ & $09: 35: 23$ & $99.944 \%$ & $99.945 \%$ & $\odot$ & $99.830 \%$ & $99.835 \%$ & - & $99.888 \%$ & $99.900 \%$ & - & 2,3 \\
\hline $25 / 02 / 2019$ & 10:38:18 & $99.940 \%$ & $99.944 \%$ & - & $99.829 \%$ & $99.834 \%$ & - & $99.886 \%$ & $99.888 \%$ & $\square$ & 1,2 \\
\hline $01 / 03 / 2019$ & 16:12:10 & $99.943 \%$ & $99.947 \%$ & I & $99.833 \%$ & $99.838 \%$ & $\square$ & $99.883 \%$ & $99.985 \%$ & ! & 1,3 \\
\hline $03 / 03 / 2019$ & 10:07:00 & $99.943 \%$ & $99.947 \%$ & 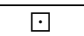 & $99.835 \%$ & $99.840 \%$ & I & $99.885 \%$ & $99.887 \%$ & $\square$ & 2 \\
\hline $04 / 03 / 2019$ & $08: 56: 04$ & $99.943 \%$ & $99.947 \%$ & . & $99.835 \%$ & $99.840 \%$ & $\odot$ & $99.885 \%$ & $99.887 \%$ & . & 1,3 \\
\hline $07 / 03 / 2019$ & $09: 35: 01$ & $99.942 \%$ & $99.946 \%$ & - & $99.830 \%$ & $99.835 \%$ & I & $99.886 \%$ & $99.888 \%$ & ए & 1,2 \\
\hline 09/03/2019 & 10:23:59 & $99.940 \%$ & $99.944 \%$ & 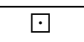 & $99.830 \%$ & $99.835 \%$ & $\nabla$ & $99.885 \%$ & $99.887 \%$ & ! & 3 \\
\hline $11 / 03 / 2019$ & 11:19:37 & $99.944 \%$ & $99.945 \%$ & $\square$ & $99.833 \%$ & $99.838 \%$ & - & $99.883 \%$ & $99.985 \%$ & $\square$ & 2 \\
\hline $12 / 03 / 2019$ & $12: 57: 20$ & $99.944 \%$ & $99.945 \%$ & - & $99.833 \%$ & $99.838 \%$ & $\odot$ & $99.888 \%$ & $99.900 \%$ & $\square$ & 1 \\
\hline $16 / 03 / 2019$ & 18:36:12 & $99.943 \%$ & $99.947 \%$ & - & $99.829 \%$ & $99.834 \%$ & I & $99.886 \%$ & $99.888 \%$ & - & $1,2,3$ \\
\hline $20 / 03 / 2019$ & $16: 22: 03$ & $99.942 \%$ & $99.946 \%$ & I & $99.830 \%$ & $99.835 \%$ & I & $99.886 \%$ & $99.888 \%$ & $\square$ & 1,2 \\
\hline $24 / 03 / 2019$ & 12:18:10 & $99.944 \%$ & $99.945 \%$ & I & $100 \%$ & $100 \%$ & . & $99.887 \%$ & $99.889 \%$ & . & $1,2,3$ \\
\hline $26 / 03 / 2019$ & $13: 17: 12$ & $99.944 \%$ & $99.945 \%$ & $\square$ & $99.829 \%$ & $99.834 \%$ & $\square$ & $100 \%$ & $100 \%$ & $\square$ & - \\
\hline $28 / 03 / 2019$ & 14:12:17 & $99.943 \%$ & $99.947 \%$ & - & $99.830 \%$ & $99.835 \%$ & - & $99.887 \%$ & $99.889 \%$ & - & $1,2,3$ \\
\hline $01 / 04 / 2019$ & 14:16:16 & $99.943 \%$ & $99.947 \%$ & $\square$ & $99.833 \%$ & $99.838 \%$ & - & $99.886 \%$ & $99.888 \%$ & $\square$ & 2 \\
\hline $03 / 04 / 2019$ & 15:14:21 & $99.944 \%$ & $99.945 \%$ & - & $99.829 \%$ & $99.834 \%$ & 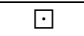 & $100 \%$ & $100 \%$ & - & 1,3 \\
\hline $07 / 04 / 2019$ & $15: 46: 35$ & $100 \%$ & $100 \%$ & - & $99.829 \%$ & $99.834 \%$ & I & $99.883 \%$ & $99.985 \%$ & $\square$ & 1,2 \\
\hline
\end{tabular}

$\left.{ }^{*}\right)$ Keterangan status bin: masih dapat diisi ( $\square$ ) dan penuh ( $\mathbf{\square}$ )

Data yang kurang dari $100 \%$ menunjukkan adanya sejumlah paket data yang gagal diteruskan dari broker ke aplikasi. Kegagalan pengiriman ini cenderung meningkat seiring bertambah cepatnya waktu jeda pengiriman data dari NodeMCU ke MQTT broker karena waktu jeda pengiriman data dari NodeMCU ke broker juga mempengaruhi waktu penerimaan data di broker. Apabila waktu pengiriman data dari NodeMCU ke broker sangat cepat, maka broker juga akan menerima data sangat cepat serta akan memiliki tugas meneruskan data tersebut ke aplikasi dengan sangat cepat juga atau dengan kata lain broker akan sangat sibuk sehingga data yang diteruskan tidak sempurna. Hal inilah yang memungkinkan hilangnya beberapa paket atau data yang seharusnya diteruskan ke aplikasi.

Secara umum, rerata realibility dan availability untuk variasi jumlah bin yang aktif terhadap variasi waktu jeda pengiriman adalah bernilai baik, dimana kegagalan sistem dalam pengiriman data dan menjalankan fungsinya hanyalah sekitar $0,055 \%-0,215 \%$. Dengan demikian dapat dikatakan bahwa performansi sistem ini dari uji realiability dan availability adalah 99,785\%-99,945\%. Selanjutnya jeda 1000 ms digunakan dalam implementasi SiKaSiT 
di daerah Bojongsoang Kab. Bandung. Pada Tabel 6, selain menampilkan realiability dan availability sistem, juga menampilkan data pemantauan ketiga bin yang dilakukan oleh salah satu pengguna melalui aplikasi Mr. Bin selama 3 bulan. Proses pemantauan tersebut dilakukan dengan melihat kondisi ketiga bin dalam waktu yang acak atau tidak teratur. Push-notifikasi "bin penuh" muncul pada layar smartphone saat sensor mendeteksi kapasitas sampah dalam salah satu atau beberapa bin sudah penuh.

\subsubsection{Performansi tampilan aplikasi Mr. Bin pada pengguna}

Data dari sensor ultrasonik dikirimkan ke aplikasi android yang ada di smartphone pengguna untuk melihat dan mengetahui keadaan tempat sampah, apakah sampah sudah penuh atau belum. Pengguna dapat memantaunya dengan membuka aplikasi pemantauan tempat sampah, disini bernama "Mr.Bin ». Kemudian pengguna dapat memilih tempat sampah (bin) mana saja untuk mengetahui kondisinya (Gambar 6). Sedangkan menu "Petunjuk Pengguna " dan menu « Pertanyaan dan Jawaban » berisikan informasi tentang instruksi manual penggunaan aplikasi dan pertanyaan-jawaban umum sebagai problem solving (Gambar 7). Namun, jika aplikasi ini tidak dibuka, maka ketika salah satu atau beberapa tempat sampah penuh, maka aplikasi ini akan memberikan notifikasi atau pemberitahuan sampah sudah penuh kepada pengguna (Gambar 8).

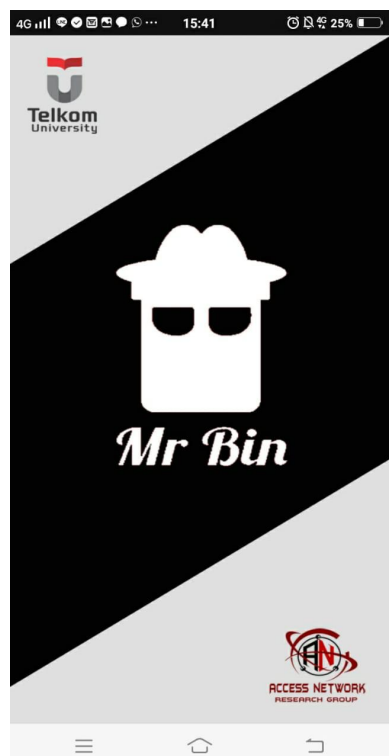

(a)

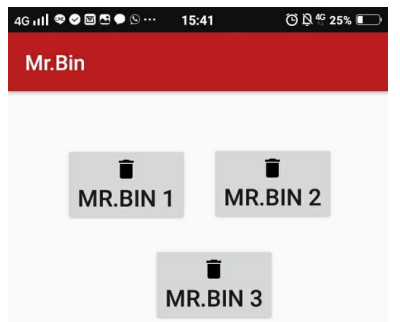

PETUNJUK PENGGUNA

PERTANYAAN DAN JAWABAN

(b)
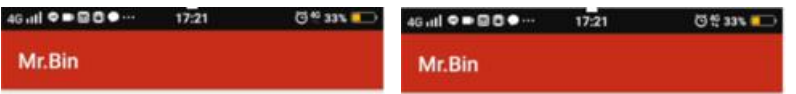

Status Mr. Bin 1

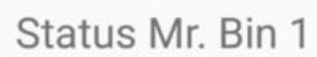

(c)

(d)

Gambar 6. Aplikasi Mr. Bin di smartphone berbasis Android. (a) Tampilan akses awal aplikasi Mr.Bin, (b) Tampilan akses pilihan oleh pengguna, dan Tampilan status atau kondisi bin 1 (c) masih bisa diisi dan (d) penuh

Spesifikasi dan performansi SiKaSiT yang dikembangkan ini memiliki beberapa kelebihan antara lain: (i) koneksi internet tidak tergantung dalam satu lingkup karena menggunakan modem, (ii) tempat sampah di desain untuk sampah kering maupun basah, (iii) pengiriman data secara real time tanpa terputus karena langsung terhubung dengan VPS. Sedangkan kekurangannya adalah belum adanya fitur mode tracking tempat sampah.

Sistem monitoring tempat sampah lain yang dikembangkan oleh Rizqi Putri N.B. dkk (21) jika dibandingkan dengan SiKaSiT memiliki kelebihan (i) packaging yang sangat sederhana dan (ii) sudah terdapat mode tracking keberadaan tempat sampah, sedangkan kekurangan dari sistem tersebut adalah (i) jika koneksi internet mati, maka data yang dikirimkan oleh sensor tidak dapat diperbaharui secara real time oleh platform, (ii) microcontroller yang dipakai terbilang lebih mahal daripada SiKaSiT, dan (iii) perangkat kemungkinan menjadi lembab jika ada sampah yang basah karena desain tempat sampah terlalu tertutup.

\subsection{Uji Kualitatif Implementasi SiKaSiT}

Dalam rangka mengetahui dan menguji tingkat keberhasilan secara kualitatif terhadap pengguna SiKaSiT ini, maka beberapa hasil feedback yang menjadi sorotan utama sebagai indikator kelancaran dan keberhasilan 
penggunaan sistem ditampilkan dalam Gambar 9 dan Gambar 10.

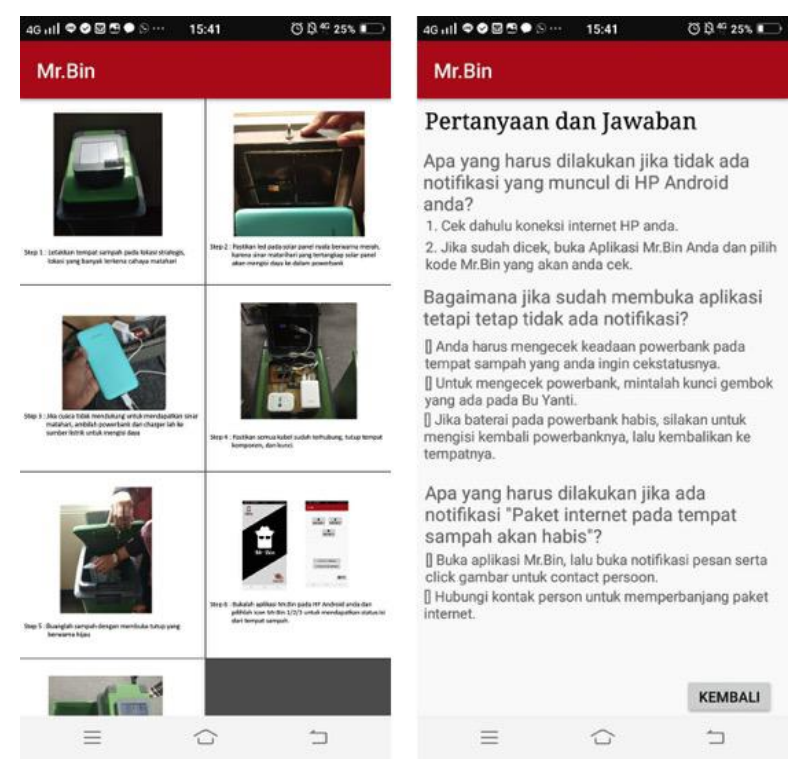

Gambar 7. Tampilan menu « Pertanyaan dan Jawaban »

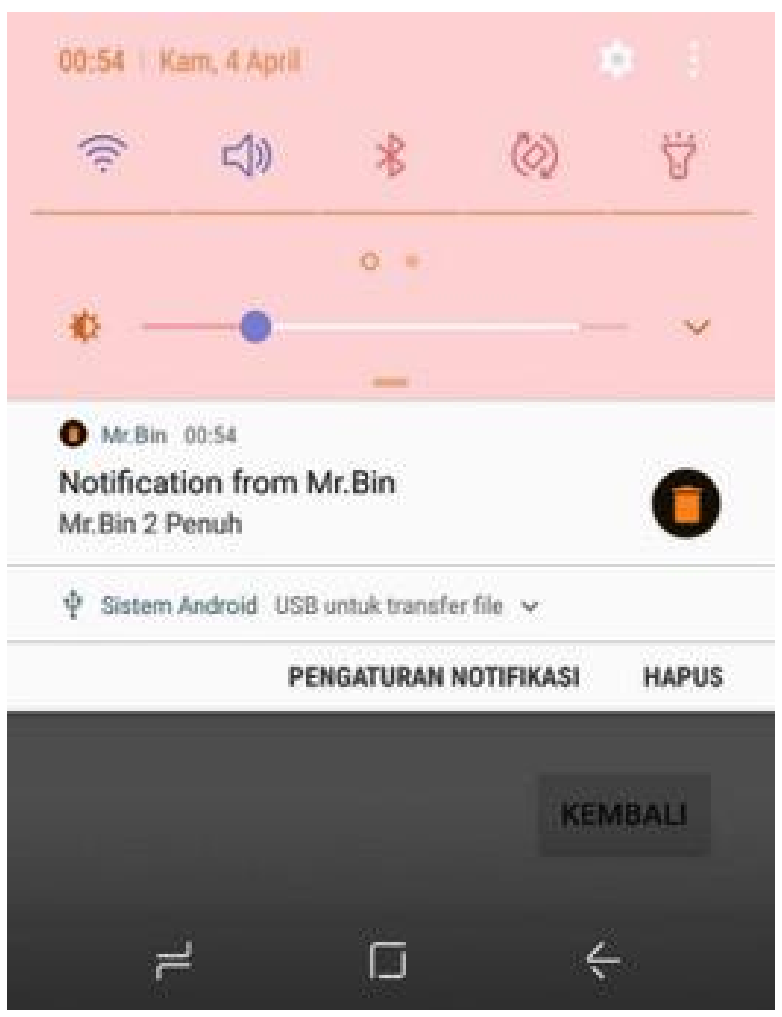

Gambar 8. Tampilan notifikasi pada smartphone ketika salah satu tempat sampah sudah penuh
Program SiKaSiT sesuai dengan kebutuhan masyarakat?

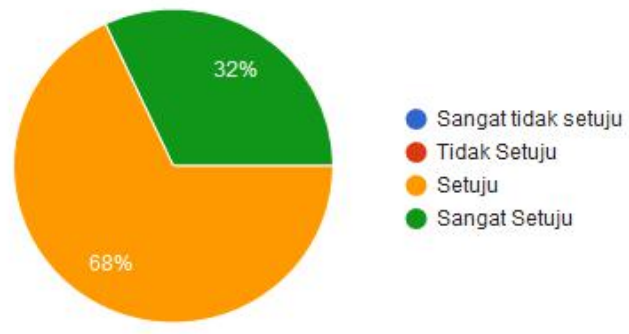

Tujuan implementasi SiKaSiT sudah sesuai dengan yang diharapkan?

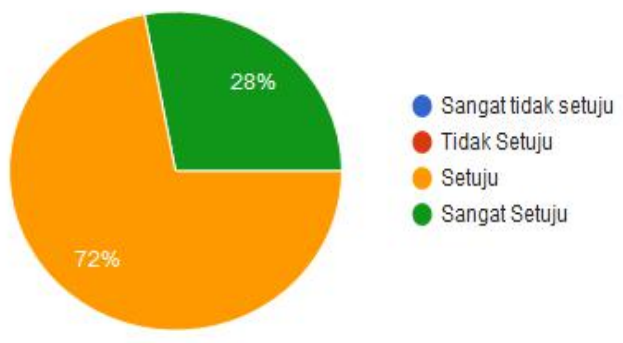

Gambar 9. Feedback masyarakat pengguna terhadap kebutuhan program SiKaSiT dan pencapaian program berdasarkan

tujuan pelaksananaannya

Waktu pelaksanaan program relatif sudah mencukupi sesuai kebutuhan?

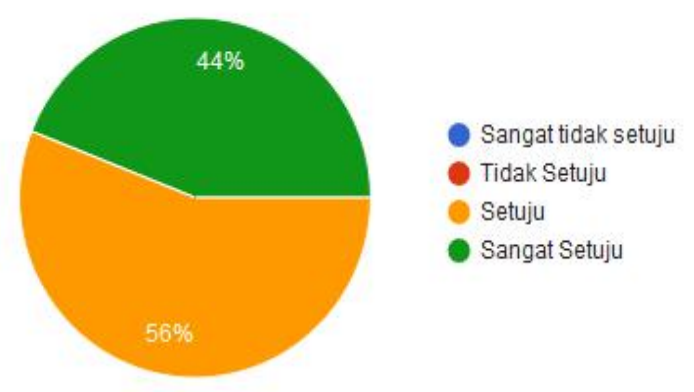

Harapan masyarakat agar program lainnya dapat terwujud dan berkelanjutan?

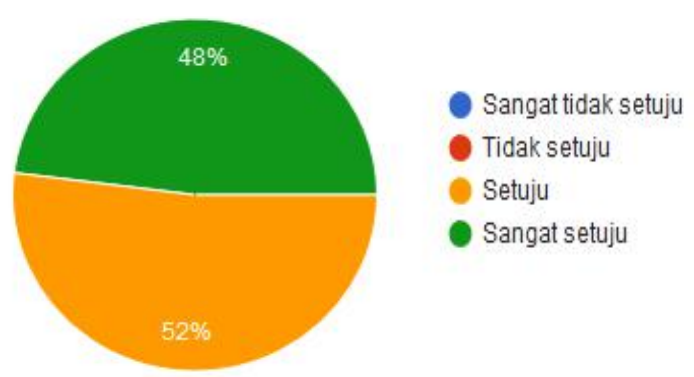

Gambar 10. Feedback masyarakat pengguna terhadap waktu pelaksanaan program SiKaSiT dan harapan kerjasama dalam penerapan program lainnya di masa depan 
Sejumlah 25 responden yang memberikan respon atau penilaian dominan sangat setuju (32\%) dan setuju (68\%) untuk kesesuaian kebutuhan masyarakat terhadap implementasi program SiKaSiT. Sedangkan untuk kesesuaian tujuan implementasi program dengan yang diharapkan, sebayak $28 \%$ menjawab sangat setuju dan $72 \%$ menjawab setuju. Jika dilihat dari kesesuaian waktu pelaksanaan program dengan masalah yang dihadapi oleh masyarakat, maka sebanyak $44 \%$ responden menjawab sangat setuju dan $56 \%$ menjawab setuju. Selanjutnya masyarakat berharap di masa yang akan datang, tim riset Universitas Telkom tetap dapat memberikan program baru berkelanjutan dalam rangka menangani permasalahan masyarakat, dimana sebanyaj $48 \%$ merespon sangat setuju dan $52 \%$ merespon setuju.

\section{KESIMPULAN}

Sistem pemantauan kapasitas sampah berbasis IoT (SiKaSiT) telah dapat memberikan solusi kepada masyarakat, khususnya petugas kebersihan dan warga Kampung Cijagra Kab Bandung. Sistem ini dibangun dengan mengintegrasikan sensor ultrasonik untuk mendeteksi volume sampah yang ada di dalam tempat sampah. Kemudian hasil deteksi sensor akan dikirimkan dari nodeMCU ke server MQTT broker yang selanjutnya akan dikirimkan dan ditampilkan pada aplikasi android di smartphone pengguna. Notifikasi keadaan sampah penuh akan dimunculkan pada aplikasi pengguna (aplikasi Mr.Bin berbasis android) jika sensor mendeteksi ketinggian sampah sudah mencapai atau melebihi batas yang ditentukan. Performansi hardware dan software dari sistem sudah berjalan dengan baik, sedangkan performansi sistem keseluruhan juga berjalan dengan baik dengan nilai reability dan availability-nya berturut-turut berkisar $(99,785$ $99,944) \%$ dan $(99,786-99,945) \%$, dimana nilai terbaiknya sangat dipengaruhi oleh tingginya waktu jeda pengiriman data dan rendahnya jumlah bin yang menyala. Selain itu, sistem ini mampu beroperasi pada jaringan internet dengan bandwith kecil karena waktu throughput yang dihasilkan adalah hanya $0.59 \mathrm{kbps}$ sehingga lebih hemat dalam konsumsi bandwith internet. Sekitar $60 \%$ feedback dari masyarakat pengguna "setuju" dan sisanya adalah "sangat setuju" menilai bahwa implementasi sistem ini berhasil dan berguna untuk mengatasi permasalahan pengelolaan sampah di kampung mereka. Beberapa saran kemajuan riset selanjutnya adalah menjadikan SiKaSiT ini sebagai prototype untuk pengembangan sistem pemantauan bin berkapasitas besar yang biasanya dibawa oleh truk pengangkut sampah. Selain itu, sistem pemantauan kapasitas sampah dalam bin ini perlu dilengkapi dengan metode pemantauan sampah yang kurang padat dan berongga serta solusinya seperti teknik penekanan atau pemadatan sampah.

\section{PERSANTUNAN}

Penulis menyampaikan terima kasih kepada PPM Universitas Telkom atas dukungan pembiayaan penelitian ini melalui Program Abdimas skema kolaborasi nasional. Ucapan terima kasih juga penulis sampaikan kepada masyarakat kampung Cijagra, Kab Bandung atas dukungan dan bantuannya selama implementasi SiKaSiT berlangsung.

\section{DAFTAR PUSTAKA}

1. Aritonang, P. L. E., Bayu, E. C., K, S. D., \& Prasetyo, J. (2017). Rancang Bangun Alat Pemilah Sampah Cerdas Otomatis. In Proc. SNITT Poltekba (pp. 375-381). POliteknik Negeri Balikpapan.

2. Budioko, T. (2016). Sistem Monitoring Suhu Jarak Jauh Berbasis Internet Of Things Menggunakan Protokol Mqtt. In Seminar Nasional Riset Teknologi Informasi (SRITI).

3. Ermawati, Y. (2012). Sistem pendeteksi kapasitas tempat smpah secara otomatis pada kompleks perumahan. Teknika, 2(3), 17.

4. Kodoatie, R. J., \& Sjarief, R. (2006). Pengelolaan bencana terpadu. Jakarta: Yayasan Watampone.

5. Nigiana, J., Larasati, E., \& Widowati, N. (2016). Manajemen Pengelolaan Sampah Di Kecamatan Tembalang. Journal Of Public Policy And Management Review, 5(1). https://doi.org/10.14710/jppmr.v5i1.10421

6. Nizar, M., Munir, E., \& Munawar, E. (2017). Manajemen Pengelolaan Sampah Kota Berdasarkan Konsep Zero Waste: Studi Literatur. Jurnal Serambi Engineering, 1(2). https://doi.org/http://dx.doi.org/10.32672/jse.v $1 \mathrm{i} 2.500$

7. Periyaldi, P., Putra, A., \& Wajiansyah, A. (2018). Implementasi Sistem Monitoring Suhu Ruang Server Satnetcom Berbasis Internet Of Things (lot) Menggunakan Protokol Komunikasi Message Queue Telemetry Transport (Mqtt). JTT (Jurnal Teknologi Terpadu) (Vol. https://doi.org/10.32487/jtt.v6i1.435

8. Raharjo, T. A. A. P., Akbar, S. R., \& Primananda, R. (2018). Sistem Monitoring Volume Dan Gas Sampah Menggunakan 
Metode Real Time Operating System ( RTOS ). Jurnal Pengembangan Teknologi Informasi Dan IImu Komputer, 2(11), 56515658.

9. Riswan, Sunoko, H., \& Hadiyarto, A. (2011). Pengelolaan sampah rumah tangga di kecamatan daha selatan. Jurnal IImu Lingkungan, 9(1), 31-39.

10.Rochman, H. A., Primananda, R., \& Nurwasito, H. (2017). Sistem Kendali Berbasis Mikrokontroler Menggunakan Protokol MQTT pada Smarthome. Jurnal Pengembangan Teknologi Informasi Dan IImu Komputer, 1(6). Retrieved from http://jptiik.ub.ac.id/index.php/j-ptiik/article/view/132

11. Rufaidah, R. A., Darlis, D., \& Hafidudin. (2014). Perancangan Dan Implementasi Sistem Monitoring Tumpukan Sampah Berbasis Mikrokontroler Dengan Notifikasi Media Sosial.

12. Safitri, A. F., \& Sukmawan, I. (2018). Perancangan sistem pemantau kapasitas tempat sampah pada skala rumah tangga berbasis mikrokontroler menggunakan sensor ultrasonik. In PPI KIM 44 (pp. 302-314). LIPI.

13. Salsalina Oktaria F. Tarigan, Imanta Herry Sitepu, \& M. H. (2012). Pengukuran Kinerja Sistem Publish / Subscribe Menggunakan Protokol MQTT. Jurnal Telematika.

14.Surjati, I., Wijono, F. S., \& Suherman. (2008). Sistem pendeteksi kapasitas tempat sampah secara otomatis pada kompleks perumahan. TESLA, 10(2), 59-62.

15. Susmarkanto. (2002). Pencemaran Lingkungan Perairan Sungai Salah Satu Faktor Penyebab Banjir Di Jakarta. Jurnal Teknologi Lingkungan, 3(1), 13-16. https://doi.org/http://dx.doi.org/10.29122/jtl.v3i 1.230
16. Utami, B. D., Indrasti, N. S., \& Dharmawan, A. H. (2008). Pengelolaan Sampah Rumahtangga Berbasis Komunitas: Teladan dari Dua Komunitas di Sleman dan Jakarta Selatan. Sodality: Jurnal Transdisiplin Sosiologi, Komunikasi, Dan Ekologi Manusia, 02(01), 49-68. https://doi.org/https://doi.org/10.22500/sodalit y.v2i1.5893

17. Yuliana, Fitriza; Haswindy, S. (2017). Partisipasi masyarakat dalam pengelolaan sampah pemukiman pada kecamatan tungkil ilir kabupaten tanjung jabung barat. Jurnal IImu Lingkungan, 15(2), 1-17.

18.Zulfikri, A. A., Perdana, D., \& Bisono, G. (2018). Design and Analysis of Trash Monitoring System Prototype Based On Internet of Things (IoT) Using MQTT Protocol. Jurnal Infotel. https://doi.org/https://.doi.org/10.20895/infotel. vol issue.page

19. ITU-T. (2012). Overview of the Internet of Things.

20. Mohammad, F.R., Eko S.P, \& Kasyful, A. (2017). Analisis Performansi dan Skalabilitas pada Event-Based loT Middleware. Jurnal Pengembangan Teknologi Informasi dan IImu Komputer., 1(7); 593-601.

21.Zavero, B.A, Widhi, Y., \& Fariz A.B. (2018). Implementasi Protokol MQTT Untuk Sistem Monitoring Perangkat loT. Jurnal Pengembangan Teknologi Informasi dan IImu Komputer., 2(12); 7521-7527.

22. Rizqi, P.N.B, Jordan, M., \& Sritrusta, S. (2018). Aplikasi DIY Smart Trash Berbasis loT Open Platform. Applied Technology and Computing Science Journal, 1(2), 93-10 